\section{THE CURRENT SOCIOECONOMIC STATUS OF UNTOUCHABLES IN NEPAL}

Thomas Cox

\section{INTRODUCTION}

\section{The Caste System and Untouchability in Nepal}

According to one definition castes - as they are found in the Hindu caste systems of Nepal and India - are "ranked endogamous divisions of society in which membership is permanent and hereditary" (Berreman 1972:198). However, it is important to realize that there are significant differences between the classical Hindu caste system, as defined in certain ancient texts such as the Manusmriti, and Nepal's caste system.

In the classical Hindu caste system, there are four varnas, or categorics, including Brahman, Kshatriya, Vaishya and Shudra. In the Nepali caste system, however, there are only three categories; Tagadhari (twice-born), Matwali (liquor drinking) and Pani $\mathrm{Na}$ Chalne (untouchables). The Tagadharis include Nepal's highest castes; Brahman, Thakuri and Chhetri. The mid-ranking Matwali include most of Nepal's Tibeto-Burman and Indo-European tribal groups. The Pani Na Chalne are untouchable caste groups who are associated with specific traditional occupations. (In this regard it is important to note that Tagadharis and Matwalis are not compelled by caste considerations to take up any one specific occupation. They may enter any one of a variety of professions - except [in many cases] those that are traditionally associated with untouchables).

Tagadhari, Matwali and Pani Na Chalne Nepalis are all rankad along an axiom of purity and pollution ( sec Sharma 1977 and Bista 1991 for a comprehensive discussion of the Nepali caste system). Tagadhari caste Nepalis are (traditionally) considered to be the most pure while Pani Na Chalne caste Nepalis are considered (under certain circumstances) to be ritually polluting (or jutho as pollution is known in Nepali). According to the rules of orthodox Nepali Hinduism Brahmans, Chhetris and Thakuris cannot accept cooked rice or water from an untouchable - or even allow them into their homes without being ritually polluted. (Some very orthodox high caste Nepalis even consider any kind of physical contact with an untouchable to be polluting. And if polluted by this kind of contact they purify themselves with water.

The Nepali caste system as described above, was codified in the National Legal Code (Muluki Ain) of 1853 by Nepal's Rana rulers. The Muluki Ain went into effect in 1854 and lasted until 1951, when the Ranas were overthrown (see Sharma 1977 and Bista 1991 for a good historical description of the Muluki Ain).

The Muluki Ain discriminated among Nepalis on the basis of caste. For example, Brahmans, as the highest ranking caste, were exempt from certain taxes and compulsory labor (for government projects) that were required from members of other castes (see Caplan 1970). Punishment for some crimes also varied depending on what caste the culprit belonged to. Brahmans, for example, were exempt from capital punishment, while members of other castes were not (Sharma 1977:285). But for some other offenses the punishment for Brahmans (and other Tagadhari Nepalis) was actually more severe than for members of lower castes. For example, high caste Nepalis who accepted cooked rice from untouchables were punished more severely than Matwalis who were guilty of the same violation (Sharma 1977:286). And while Brahmans were not subject to capital punishment they could be stripped of their high caste status and brought down to the rank of untouchable for certain offenses - including incest, murder, rape, marrying an untouchable or accepting water from them (Sharma 1977:285).

The constitution of 1963 abolished the Muluki Ain and, further, outlawed all discrimination on the basis of caste. And yet there is still a caste system in Nepal. The strength of the system varies, to a certain degree, from one part of the country to another. And there is considerable variation in the extent to which individual Nepalis follow caste-based principles. But the fact remains that untouchables in Nepal continue to be discriminated against in a variety of ways, and that this is one major reason why their socioeconomic status (relative to that of other castes) remains poor.

Many development policy makers in Nepal have become concerned about the problems faced by untouchables. In an effort to better understand these problems some officials have implemented studies on the socioeconomic situation of untouchables in Nepal. Much of the data in this paper comes from 
two such studies. In one, completed in January of 1994 , Save the Children USA (an international NGO), with funding from the United States Agency for International Development, surveyed 751 untouchables in 5 different districts, one in each development region in Nepal. In another much more limited study, in 1992, Save the Children conducted a socioeconomic survey of 30 untouchable households, again, in 5 districts representing all of Nepal's development regions (see Cox 1992 and Sharma 1994). ${ }^{1}$

\section{Organization of the Article}

This article begins with a description of the different untouchable castes found in Nepal. This is followed by an analysis of the discrimination faced by untouchables. The third section discusses economic conditions and educational achievement in Nepal's untouchable communities. The fourth section gives recommendations for raising the socioeconomic status of untouchables in Nepal. The final section is a conclusion which goes over major points made in the article.

\section{UNTOUCHABLE CASTES IN NEPAL}

Untouchable castes in Nepal can be divided into three different categories; (1) Those living primarily in the terai (the southern plains of Nepal). These include Dum, Teli, Musuhar, Dusadh and Sundi (among others). (2) Castes that are predominantly found in the middle hills. These include (among others) Kami, Damai and Sarki (who have higher respective populations than any other untouchable caste groups in Nepal). (3) Newar untouchable castes (the Newar are an ethnic group - who speak a Tibeto-Burman language - indigenous to the Kathmandu valley. They have a complex, highly stratified society that includes both Buddhists and Hindus). These include Kasai, Pode, Chyame and Kusle (see also Sharma 1994 for a description of these castes).

What follows is a description of the untouchable castes discussed in this article and surveyed in the two studies conducted by Save the Children.

Badi: Until the 1960's most Badi worked (primarily) as traveling entertainers, dancing and singing at festivals, weddings and parties. Over the last 30 years, however, prostitution has become the primary occupation for Badi women, while Badi men usually fish and make drums. Badi are found in the Banke, Bardiya, Kailali, Dang-Deukhuri, Rukum, Rolpa, Dailekh and Doti districts of far west Nepal. With a total population of about 7000 they are one of the smaller untouchable castes in Nepal (see Cox 1993).

Damai: Damai are found all over Nepal. Their traditional occupation is tailoring, although some Damai also work as entertainers, playing musical instruments (such as the drum and flute) and dancing and singing at weddings and festivals.

Dum: Dum are migrants from India who live, primarily, in urban areas of the terai working, for the most part, as sweepers.

Gaine: Gaine live all over Nepal. Their traditional occupation is entertainment and, more specifically, playing an instrument known as the Saringe and singing. Some Gaine also fish and make Saringes and sell them to tourists.

Hudke: Hudke originally lived in the Jumla area of far west Nepal. But 25 years ago they migrated to Surkhet, where they live (as squatters) on government land and work as laborers and entertainers (see Sharma 1994).

Kami: $\quad$ Kami are found all over Nepal. Their traditional occupation is metal working. Kami living in villages usually make and repair agricultural implements, pots and pans, chains, locks and other hardware. Kami who live in bazaar areas often make and sell jewelry.

Kasai: $\quad$ Kasai are a Newar caste who live in most of Nepal's major bazaar towns. Their primary occupation is selling meat. Most Kasai manage their own butcher shops.

Kusle: $\quad$ Kusle are a Newar caste who live, mainly, in large bazaar towns. Their traditional occupation is cleaning temples and putting on musical performances (usually inside the temple).

Musuhar: Musuhar originally came from India and are found, primarily, in the Jhapa district of southeastern Nepal. Their traditional occupation is brick making and other kinds of labor associated with construction. Some Musuahar speak Maithali as their native language and do not even know Nepali.

Pode: Pode are a Newar caste who live in urban areas throughout 
Nepal and make their living, primarily, as sweepers.

Sarki: $\quad$ Sarki have a large population that is spread all over Nepal Their traditional occupation is shoe-making.

\section{DISCRIMINATION}

In the 1993 Save the Children study $84 \%$ of the total 751 untouchable respondents reported that they had been subjected to caste-based discrimination. ${ }^{2}$ The kinds of discrimination reported included; (1) Not being allowed to take drinking water from taps used by members of higher castes. (2) Not being allowed inside hotels, restaurants, shops or high caste Nepalis' homes. (Another common complaint was being forced to wash glasses or plates after eating in a restaurant). (3) Not being allowed inside temples. (4) Not being allowed to sit or eat with high caste people at social events (these include school functions, wedding feasts, etc. $)^{3}$ (5) Being denied jobs - especially higher-level managerial positions - even when they are qualified for them.

It is important to realize that the nature and degree of caste-based discrimination varies considerably from one part of Nepal to another. ${ }^{4}$ Castebased discrimination appears to be far more prevalent in far western Nepal than in other parts of the country. In the 1993 Save the Children study, for example, $69 \%$ of untouchable respondents in Jhapa, and $71 \%$ in the south-central district of Chitwan, reported discrimination by high-caste Nepalis, whereas in the far western districts of Kailali and Surkhet the figures were $90 \%$ and $94 \%$ respectively. ${ }^{5}$ The reason for this discrepancy is that:

"The isolation of far west Nepal has, to a significant extent, preserved Hindu orthodoxy in all its manifestations - including caste-based discrimination. In central and eastern Nepal, however, traditional Hindu norms have changed, due to an influx (facilitated by communication and transportation links) of new ideas and institutions" (Cox 1992:6).

Caste-based discrimination in the far western district of Doti appears to be particularly severe. High caste people there not only purify themselves with water each and every time they are touched by an untouchable, but also sprinkle water on themselves after returning home from trips to a crowded bazaar, out of concern that they might have been touched by an untouchable without being aware of it. In Doti all untouchables are: (1) Strictly forbidden to take water from taps used by members of higher castes and; (2) Always required to wash their own dishes and glasses after eating in a restaurant (Sharma 1994:62).
In Jhapa, by contrast, very few high caste Nepalis will purify themselves with water after being touched by an untouchable. And only $15 \%$ of untouchables surveyed in Jhapa (in the 1993 Save the Children study) reported instances of not being allowed to take water from taps used by high caste people. In addition less than $5 \%$ of surveyed Jhapa untouchables reported that they had been required to wash their own glasses or dishes after eating in a restaurant (Sharma 1994:62).

Ongoing discrimination adversely affects untouchables in many different ways. For example, in some communities high caste Nepalis monopolize the best (i.e. cleanest and most reliable) sources of drinking water, leaving untouchables with unclean water that threatens their health. For example, in a village north of Pokhara high caste and Matwali Nepalis refused to let untouchables take water from local community taps. As a result many untouchable families were forced to drink the dirtier water that ran through the rice paddies. One consequence of this was that untouchables in this village had a much higher rate of gastrointestinal disease than members of higher castes (Macfarlane 1981:85).

In Doti untouchable students (in all primary and secondary schools) are not allowed to touch the drinking water pitcher that is kept in the classroom. As a result thirsty untouchable students often have to go outside the school in search of water. In one such instance an untouchable boy studying in Dipayal was forced to go to the Seti River, and while trying to get a drink fell into the raging torrent and drowned (Sharma 1994:80-81).

Refusing untouchables entry into Hindu temples is one of the most common forms of caste-based discrimination in Nepal. Indeed, $54 \%$ of the untouchables surveyed in the (1993) Save the Children study reported that they were not allowed to enter local Hindu temples. Many untouchables find this kind of discrimination to be particularly outrageous, as they feel, like most Nepalis, that religious practice is a fundarnental human need, and, further, that since they are also devout practicing Hindus, that access to Hindu temples is their basic right. Despite this kind of discrimination however, the majority of untouchables in Nepal continue to follow Hinduism. ${ }^{6}$ Ninety-seven percent of the untouchables in the (1993) Save the Children study said they were Hindu. The remaining three percent were Christian or Buddhist (Sharma 1994:16) ${ }^{7}$

An unwillingness to give higher, professional level positions to untouchables, even when they are qualified for them, is another common manifestation of caste-based discrimination in Nepal. ${ }^{8}$ And even if untouchables are given professional positions they are sometimes still persecuted or even 
dismissed for no reason. What follows are case studies of these kinds of discrimination.

A Sarki man received his intermediate degree and shortly thereafter was hired as a teacher at a government primary school in Kaski district. From the beginning he was maliciously teased by the students and ostracized by other high caste teachers and members of the local community. These people eventually convinced members of the Kaski District Education Administration to fire the Sarki teacher and replace him with a high caste Nepali. After his dismissal the Sarki man enrolled in Prithivi Narayan Campus' B.A. program. But after his bitter experience as a teacher he is not confident that another degree will enable him to find a job (Sharma 1994:30).

An untouchable man in Doti, with all the formal credentials needed to qualify for a teacher's position, approached a visiting minister to ask for help in obtaining just such a post. The Minister dismissed the request saying. "I cannot help you in this matter because high caste people would never accept an untouchable as a teacher" (Sharma 1994:32).

An untouchable man in Kailali was hired as a high school teacher in Kailali district. After assuming his position he noticed that high and low caste students were forced to sit separately during school lunches. Determined to stop this discrimination he encouraged all the students in his class to sit and eat together. The school's Brahman headmaster found out about this and had the teacher transferred to another school (even though independent school inspectors had determined that the teacher's performance was satisfactory) (Sharma 1994:32).

There have also been instances where untouchable businessmen have been discriminated against, in ways that threatened their livelihood. In one such case, high caste employees at a milk collection center in Syanja refused to buy milk being supplied by untouchables, remarking that it "stank like a blacksmith". Local untouchable residents protested against this action, pointing out that the constitution of Nepal forbids caste-based discrimination. Local high caste residents, in collaboration with milk collection center officials, responded by moving the milk collection center to a local temple that untouchables were not allowed to enter. Soon after a meeting was held in an attempt to resolve the dispute. But this meeting ended in a bitter argument in which nothing was resolved. As of December, 1993 both sides remained completely polarized. Local high caste officials still refused to buy milk from untouchables, and the untouchables responded by initiating legal proceedings against them: (Sharma 1994:77)
In another similar case the Brahman Chairman of a milk production center in Jayanagar stopped buying milk from a local Kami man, just because he was an untouchable. The Kami reported the case to the Depressed Caste Emancipation Society. The society then organized a meeting in an attempt to resolve the dispute. During this meeting local untouchable residents, with the support of the Chief District Officer, told the Chairman to resume buying milk from the Kami dairy farmer, or face a lawsuit. The Chairman apologized for what he had done and promised to start buying the Kami's milk again (Sharma 1994:76).

\section{Untouchables' Responses to Discrimination}

In their 1993 study, Save the Children researchers asked all surveyed untouchables how they had responded to discrimination. Only fourteen percent of those surveyed had ever responded with protests. Fifty-six percent of surveyed untouchables had remained silent in the face of discrimination, even though they believed it was unjust. Another twenty-nine percent of respondents had accepted discrimination, saying it was their inescapable, god-determined fate (Sharma 1994:63).

Many untouchables are pessimistic about their chances of receiving social justice by protesting against caste-based discrimination. They assume that Nepali legal officials - most of whom are Brahmans, Chhetris or Thakuris (or high caste Newars) - will almost always side with high caste Nepalis in any dispute involving untouchables.

The Save the Children researchers found 31 instances in which untouchables filed lawsuits in response to alleged caste-based discrimination. In only seven of these cases did the judge rule in favor of the untouchable (Sharma 1994:68)

Without knowing the details of these cases it is difficult to say with certainty whether the low success rate of these lawsuits is a result of high caste bias or not. Nonetheless, when discrimination suits (apparently) have such a low success rate it is understandable that many untouchables are hesitant to file them at all (especially when one also considers the time, effort and expense involved in taking such legal action).

A low level of awareness about the rights that are due to them under Nepali law is another reason why so many untouchables do not protest against 
caste-based discrimination. Indeed, in the 1993 Save the Children study only $9 \%$ of untouchable respondents knew that caste-based discrimination was outlawed in Nepal (Sharma 1994:67).

Untouchables also have a very low rate of involvement in NGOs, political groups or other organizations that could (potentially) assist them in combating caste-based discrimination. In the 1993 Save the Children study only $6 \%$ of untouchable respondents were actively involved in any $\mathrm{NGO}(\mathrm{s})$, and only $4 \%$ were active in a political organization or party (Sharma 1994:65-66).

Fatalistic, accepting attitudes towards caste-based discrimination appear to be most prevalent among untouchables in remote parts of west Nepal where the caste system is still very strong. In Doti, for example, the majority of untouchables accept the caste system, accept the theory that people should be ranked along an axiom of purity and pollution, and that certain occupations should only be performed by members of particular castes. Indeed, in describing themselves and why they accept their place in the caste system, Doti untouchables often state a Nepali proverb; "you can't make a cow out of an ass" (Sharma 1994:63) ${ }^{9}$ Many Badi in the districts of Banke, Dang-Deukhuri and Kailali have a similar attitude (Cox 1993:11).

\section{THE CURRENT EDUCATIONAL AND ECONOMIC STATUS} OF UNTOUCHABLES IN NEPAL

\section{Educational Status}

Before 1951, there were not many schools in Nepal. And in the schools that were established untouchables were usually not allowed to enroll and, thus, generally received little or no education (Sharma 1994:30). Because of this lack of education, and ongoing discrimination, untouchables were, generally, unable to compete for professional positions (i.e. government posts or jobs in medicine, law, teaching, accounting, etc.). As a result most untouchables ended up working in their traditional caste-based occupations and/or as menial laborers.

The 1963 constitution guaranteed all untouchables access to education in government primary and secondary schools (and colleges as well). But mos untouchables have still been unable to afford an adequate education for their children. Sometimes parents have been unable to pay school fees, or buy books and/or stationary. On other occasions parents have been able to afford initial school-related expenses, only to have their children be forced to drop out in a few years and work to support their aging parents and/or younger siblings (and themselves).

Fourteen percent of the untouchables surveyed in Save the Children's 1993 study had a primary school education. This is not far below the national average of $16 \%$ (for all castes). And $8.3 \%$ of surveyed untouchables had a secondary school education. This is also not far below the national average of $8.8 \%$. But at higher educational levels the gap between untouchables and other castes widens considerably. Only $0.8 \%$ of untouchable respondents had passed the SLC (taken after 10th class). This is significantly below the national average of $1.98 \%$. At the college level the gap widens even further. Only $0.3 \%$ of surveyed untouchables had studied up to the Intermediate level, whereas the national average is $0.9 \%$. And only two untouchable respondents (both men), a mere $0.04 \%$ of the whole sample, had studied up to the B.A. level, far below the national average of $0.64 \%$ (see Sharma 1994: 19 and the Central Bureau of Statistics Records). 10

\section{Economic Status}

Even when untouchables receive a college degree they often still have a difficult time finding a professional position. Many high caste Nepalis (as was previously discussed) are reluctant to hire untouchables.

Untouchables' efforts to find jobs are also often hampered by their lack of kinship or social connections with high caste people in positions of authority. In Nepal people in high positions often arrange jobs for their relatives and/or friends (afnu manchhe as they are known in Nepali). The importance of these afnu manchhe connections give high caste Nepali job seekers a big advantage over untouchables. This is because there are far more high caste Nepalis than untouchables in high positions. This means that high caste Nepalis usually have far more connections to draw upon in their search for work than untouchables do (see Bista 1991 for an excellent analysis of the importance of afnu manchhe connections in $\mathrm{Nepal}$ ). In many cases untouchables who have a college degree are unable to find a professional position and, thus, end up working in their traditional caste occupation.

In the 1993 Save the Children study ninety-seven percent of untouchable respondents reported that they were working in their traditional caste occupation and/or as menial laborers (some of these respondents also worked their own land 
as subsistence farmers). Only $3 \%$ had professional positions in the government or private industry (Sharma 1994:49).

The majority of Save the Children's untouchable respondents also had a low average annual income. The highest proportion, $41 \%$, averaged less than 10,000 rupees in annual income. Thirty-seven percent averaged between 10,000 and 20,000 rupees, and twenty-two percent had an average annual income of more than 20,000 rupees (Sharma 1994:50).

Fifty-seven percent of untouchable respondents reported that their income was not enough to meet basic subsistence needs (Sharma 1994:50) ${ }^{11}$ As a result of such deficits $60 \%$ of surveyed untouchables had to borrow money to pay for food, clothing and/or medical expenses (Sharma 1994: 51).

In conclusion it may be said that most Nepali untouchables are caught in a vicious economic cycle. They are unable to receive an education that would qualify them for a well-paying professional position. This means that most of them end up working in their traditional caste occupation and/or as unskilled laborers, usually for a limited income. Consequently, they are unable to give their own children an adequate education and the whole cycle repeats itself. ${ }^{12}$

\section{RECOMMENDATIONS}

The problems faced by untouchables in Nepal have, until recently, been (generally) neglected by the Nepali government and development agencies (both domestic and international). Addressing these problems is imperative, not only to raise the socioeconomic status of Nepali untouchables, but also to facilitate a more general development process that would benefit all Nepalis. Caste-based discrimination, poverty and low levels of educational achievement prevent most untouchables from realizing their professional potential. If more untouchables could realize this potential it would, in the long run, benefit other Nepalis as well.

Take the example of Dr. Ambedkar. Ambedkar, an untouchable, overcame discrimination and other obstacles to become one of India's greatest leaders. Indeed, he drafted India's constitution, an achievement that benefited all Indians regardless of caste. Ambedkar then went on to lead untouchables in a movement against caste-based discrimination. Throughout this movement Ambedkar emphasized peaceful, rational, politically sophisticated action as a solution to untouchables' problems. In the hands of a lesser man the movement could have degenerated into violence and chaos that would have intensified untouchables problems instead of alleviating them.

One can only hope that ongoing and future development efforts in Nepal will facilitate the rise of many Ambedkars, who will work for the good of all Nepalis. What follows are some recommendations to improve the socioeconomic situation of untouchables in Nepal.

\section{Educational Support}

Needy untouchable students, who are both motivated and academically qualified, should be targeted for scholarships at the primary, secondary, undergraduate and graduate levels. These scholarship programs should be implemented by government and private (domestic and/or international) agencies, in collaboration with local-level NGOs. The government, and/or any involved agencies, could provide financial backing and technical support, while the NGOs could be active locally, selecting scholarship recipients, monitoring their progress, arranging tutorial heip and providing general moral support and assistance in resolving any school-related problems.

One such program is already running successfully. The Nepal Scholarship Endowment Program (NESP), which began in January of 1992, has been implemented by the Nepal National Social Welfare Association (a Nepali NGO that is working to improve the quality of life for untouchables in 65 districts of Nepal) in collaboration with Save the Children USA and with financial support from the United States Agency for International Development. The NESP has given scholarships to over 300 untouchable (and tribal) high school students in 16 districts. But this one program is not nearly enough for all the needy untouchable students in Nepal. The government and concerned development agencies must take the initiative to start similar programs. ${ }^{13}$

\section{Institution Building}

Nepalis should be encouraged to establish organizations that protect untouchables' rights, and work to improve the overall quality of their life. These organizations could implement the scholarship programs proposed above. Other potential programs could focus on health education, legal education, family planning and income generating activities.

Ideally, these programs, to the fullest extent possible, should be run by 
locally based untouchables, as they are the ones who know the most about local conditions and have the closest ties with target community members. In the process of running these programs local untouchables would also be able to develop their managerial and leadership skills. ${ }^{14}$

\section{Legal Aid}

The Nepali government should establish a commission to investigate the nature and extent of caste-based discrimination in Nepal. On the basis of this commission's findings the government should adopt new policies that effectively address the problem. In addition, the govemment, and other concerned agencies, should establish community education programs that inform untouchables of their rights under Nepali law, and action they can takc in response to discrimination.

\section{Consciousness Raising}

All Nepali students, in both primary and secondary schools, should be given talks and readings that address the problem of caste-based discrimination. Students should be taught: (1) Why the cultural-idcological basis of caste-based discrimination is false; (2) About different kinds of caste-based discrimination and how they adversely affect Nepalis; (3) About existing laws against discrimination and; (4) The role that they can play in breaking down caste-based discriminatory attitudes.

\section{Income Generation}

Through the Nepali government and/or private (domestic and international) agencies, programs should be implemented to raise the income of untouchables involved in traditional caste occupations. These programs could include training to improve untouchables' technical and business management (including accounting, market surveying and preparation of business plans and bank loan applications) skills. In addition, untouchables should be encouraged to form themselves into cooperative savings groups to finance their individual income generating activities. Some bank officials should also be recruited (by concerned NGOs or other organizations) to educate untouchables about the kinds of loans that are available to start up businesses, and how they can be obtained.

\section{SUMMARY}

This article has argued that there is still caste-based discrimination in Nepal, and that this is a major reason for Nepali untoucables' current poor socioeconomic status. The article began with a short history of Nepal's caste system. This was followed by a description of the different untouchable castes found in Nepal. The next section focused on different kinds of caste-based discrimination in Nepal. This was followed by an analysis of the economic and educational status of untouchables in Nepal. In this section I concluded that a lack of education (reinforced by discrimination) limits untouchables' economic options, making them dependent on their traditional caste occupations and unskilled labor. This economic dependence has, in turn, impoverished many untouchables to the point that they cannot adequately educate their children. Thus, many untouchables remain trapped in a cycle where poverty and lack of education reinforce each other. The final section gave recommendations for raising Nepali untouchables' socioeconomic status. These included implementing educational support, institution building, legal aid and income generating programs in untouchable communities (as well as raising awareness - among Nepali students from all different castes - about the problem of caste-based discrimination).

\section{FOOTNOTES}

1. Gopal Sunar (Save the Children's Scholarship Program Manager) and I conducted the limited 1992 study. In the more comprehensive 1993 study I served as an advisor. I helped plan the study and accompanied the team (of 13 researchers) to Kaski District where we spent eight days conducting interviews. It was during this period that we collected data on the Kumal (see footnote number eleven), economic status of the Kasai (see footnote (see foot was Project Coordinator. He supervised research activities in all five target districts and wrote the final report.

2. In the 1992 study $62 \%$ (eighteen out of thirty) of all surveyed untouchables said they had been discriminated against by high caste Nepalis. All nine $(100 \%)$ untouchables surveyed in the far western districts of Kailali and Bardiya reported discrimination whereas only nine out of eighteen $(50 \%)$ untouchables surveyed in central and eastern Nepal reported the same problem. 
3. Orthodox Hindu caste values forbid Brahmans, Chhetris and Thakuris to marry untouchables. Nonetheless, such marriages sometimes do occur. In one case that I know of a Brahman woman married (against her parents' wishes) an untouchable Damai man. The woman was subsequently disowned by her parents and brothers. Her brothers were reported to have said, "If we accepted this marriage we would have to touch our head to the feet of our brother-in-law whenever he came into our house. How can we touch our head to the feet of an untouchable." (According to Nepali custom men are supposed to touch their head to the feet of brother-in-laws when they come to visit).

I also know a Chhetri man who is happily married to a Badi woman. He met this woman and married her after his mother and father died, so parental opposition was not a problem. Indeed, the man admitted that if his parents had been alive he probably never would have married a Badi (Cox 1993: 4).

4. The extent to which untouchables are discriminated against is often dependent, to a degree, on their personal qualities and achievements. For example, I know 3 Badi girls who have not been discriminated against by high caste Nepal is (this stands in sharp contrast to most other Badi girls who are subject to various forms of discrimination, including severe harassment by some high caste Nepalis). These three girls are excellent students and are considered (by both other Badi and high caste Nepalis) to be very personable and attractive. These girls' personal qualities and academic success have given them a certain status that has defused potential caste-based discrimination (see Cox 1993: 14).

I also know several wealthy, successful untouchable businessmen who have, generally, not been subjected to caste-based discrimination (whereas the poorer, professionally undistinguished untouchables living around them have). Again, wealth and professional success give these untouchables a certain status that, to an extent, shields them from caste-based discrimination.

5. Untouchables also often discriminate against each other on the basis of caste. For example, Hofer (1976:354) reports that Kamis (in a village west of Kathmandu) do not let Damais into their homes or accept water (or cooked rice) from them.
6. Hinduism in Nepal is a syncretic religion which often differs significantly from one village to the next. Different communities select some traditions from orthodox Hinduism, but reject others, worship certain local deities that are not found elsewhere, and often follow certain Animist traditions as well (Cox 1993: 10). And many Nepalis are keenly aware that their local version of Hinduism differs from the more mainstream (or "great tradition") Hinduism that is found in major religious centers of India. Indeed, when I asked untouchables north of Pokhara what religion they followed many of them replied "Nepali Dharma" (Nepali Religion) to express the fact that their syncretic Hinduism differs significantly from Hindu traditions in India.

7. In the 1950 's India's great untouchable leader, Dr. Ambedkar, led thousands of untouchables in a mass conversion to Buddhism, to protest against orthodox Hinduism and the caste-based discrimination that often goes with it.

8. Caste-based discriminatory principles often have an adverse impact on Brahmans, Chhetris and Thakuris, as well as untouchables. For example, I know a Chhetri man in Pokhara who wanted to open up a khukuri (a knife with a long curved blade) factory, but felt that he could not (even though he was convinced that the enterprise would be profitable). Khukuris in Nepal are traditionally made by Kamis. The Chhetri man was worried that he would lose status by taking up an occupation traditionally associated with untouchables.

9. In Nepal's Hindu society cows are sacred, the epitome of ritual purity, whereas asses (i.e. donkeys) are thought to be more jutho (ritually polluting). Thus, when fatalistic Doti untouchables say, "You cannot make a cow out of an ass," that can be translated as, "You cannot make a ritually pure being out of one who is polluted."

10. One reason why so few untouchables go to college or graduate schools is that they lack role models. They usually do not know of any untouchables who received an undergraduate or graduate degree and then went on to establish themselves as a professional in medicine, law, business or any other field. As a result untouchable students of ten assume that untouchables in general have no chance of becoming professionals. If there were more successful untouchable professionals in Nepal they could constitute valuable role models who could motivate untouchable students by showing them 
that untouchables can be just as academically and professionally successful as high caste Nepalis.

11. Current market forces have made some untouchables' traditional occupation less lucrative than before, and others more so. The Sarkis, for example, have seen the market for their hand-made shoes go down in recent years due to stiff competition from cheaper, factory-made foreign imports. The Kasai, on the other hand, have benefited greatly from a recent expansion in the market for meat. Rising incomes among the urban middle class have enabled many Nepalis to purchase more meat than before. And religious prohibitions (which applied primarily to Brahmans and Chhetris) against eating meat have been relaxed, further facilitating an expansion in the market for poultry, mutton and pork.

12. Because uneducated untouchables generally have very limited economic options they become vulnerable to exploitation and shifting market forces. This vulnerability was very apparent in the squatters' settlement of Azurtebat (near Guleria in the terai zone of Bardiya district) which I visited in July of 1992. Thirty-seven out of the forty families in Azurtebat were Kami or Damai. And none of them had more than a fifth class education. These untouchable families had come to Azurtebat from different villages in the hills. Some had come after losing their land (usually because they sold it to pay off a debt). Others were unable to make a living from their traditional occupation. Two families had worked as tenant farmers, but were not given their rightful share of grain by the landlord and, thus, had to leave. All of these families had come to the terai in search of land, and eventually hoped to make a living as farmers. If the untouchable squatters of Azurtebat had received more education, they probably would have had more economic options, and not been forced into such as desperate situation.

In August of 1993 Save the Children researchers and I interviewed twentyfour Kumals (a tribal group whose traditional occupation is making pottery) in the village of Argau (which lies just east of Pokhara). While the Kumal are not untouchables I am including their case study here, as it constitutes a particularly instructive example of how whole communities with limited income generating options can become impoverished by certain economic (or, in this case, environmental) forces. Almost all of the Kumal families in Argau previously made their living as potters. They made ceramic ware in their own homes and sold it in Pokhara. And most of them had a fair to good income. But as nearby forests were being rapidly cut down it became increasingly difficult for Argau Kumal to obtain the firewood necessary to fire their pots. Finally, firewood became so scarce that by 10 years ago almost all Argau Kumal had given up pottery-making. Many of them were subsequently forced to work as low-paid unskilled laborers. Some others have not been able to find any work at all (and the vast majority of these Kumal did not have the education necessary to get better jobs). Many Kumal families have been forced to sell their valuable agricultural land to pay off debts and/or meet basic subsistence needs.

13. I am against any policy that would require employers, in either government or private offices, to give some jobs to untouchables. There are three major problems with this kind of policy: (1) The reserved jobs usually go to rich, well-connected untouchables who would have found employment anyway; (2) Untouchables might think they don't have to work hard to build up their professional credentials since employers will be forced to hire them no matuer what. (It is better to create educational opportunities that will allow untouchables to successfully compete for jobs on the open market); (3) This policy could intensify high caste resentment against untouchables.

14. There are many intelligent, well-educated untouchables in Nepal who have leadership potential, who could really help other untouchables if they wanted. But in many cases highly educated, well-off untouchable Nepalis distance themselves from other untouchables, and, in many cases end up having a closer relationship with high caste people. I even know one wealthy untouchable man with a master's degree, and a high managerial position, who gave his children a new last name - a Chhetri name - in a deliberate attempt to shed their untouchable status. The fact of the matter is that even though highly educated, wealthy untouchables may not be persecuted - to the same degree as those who are poor and uneducated - they are still, to an extent, stigmatized, and think they would create new social and professional opportunities for themselves (and their families) by associating more with high caste Nepalis and less with untouchables.

Another reason why wealthy, well-educated untouchables often do not become leaders is that they tend to be relatively comfortable, usually experience a minimum of caste-based discrimination, and, thus, are never radicalized to the point that they want to dedicate their lives to the fight against caste-based discrimination.

All over the world the greatest, most committed minority leaders are those 
who initially suffered as a result of racism, and then dedicated the remainder of their lives to the struggle against it. Indeed, it is no accident that the greatest African-American leaders - and I am referring here to Malcom X and Martin Luther King - rose to prominence before the Civil Rights Act of 1964. These men grew up in an age when African-Americans had to face racism daily, and had no burgeoning, comfortable, professionally successful black middle class to take refuge in. Malcom X and Martin Luther King chose to fight that which they could not escape. Similary, Dr. Ambedkar was radicalized by discriminatory acts before he became a leader of India's untouchables. And in Nepal as well, a very successful young Tharu leader, Dilli Bahadur Chaudhary, was initially radicalized by the theft of his family's land (by a high caste landlord), before leading a grass-roots movement - with over 75,000 members - to liberate other oppressed Tharu (such as bonded laborers).

Berreman, Gerald D. 1972

\section{Bista, Dor Bahadur} 1991

\section{Caplan, Lonel} 1970

Cox, Thomas E. 1992

\section{BIBLIOGRAPHY}

Hindus of the Himalayas. Berkeley: University of California Press.

Fatalism and Development. Calcutta: Orient Longman.

Land and Social Change in East Nepal. London: Routledge and Kegna Paul.

Academic Environment and Achievement Among Students in the Nepal Scholarship Endowment Program. A report submitted to Save the Children USA.

The Badi : Prostitution as a Social Norm Among an Untouchable Caste of West Nepal. Kathmandu: Asian Ethnographer Society Press.
Hofer, Andras

1977

Macfarlane, Alan 1981

1994

Sharma, Prayag Raj 1977
"A Settlement and Smithy of the Blacksmiths (Kami) in Nepal". Kailash, Vol. 4, No. 4, pp. 349396.

"Death, Disease and Curing in a Himalayan Village". Asian Highland Societies in Anthropological Perspective. edited by Christopher Von Furer Haimendorf. New Delhi: Sterling Publishers, pp. 79-130.

A Modest Study of the Current Socioeconomic Situation of the Lowest Status Caste and Tribal Groups in Nepal.

A report submitted to Save the Children USA.

"Caste, Social Mobility and Sanskritization: A Study of Nepal's Old Legal Code." Kailash, Vol. 5, No. 4, pp. 277-299. 